\title{
MANUSIA SEBAGAI PENDIDIK PERPEKTIF ISLAM DAN BARAT
}

\author{
Muhammad Arsyam ${ }^{1}$, Kusnadi Umar², Zakirah Zakirah ${ }^{3}$ \\ ${ }^{1}$ Sekolah Tinggi Agama Islam (STAI) Darul Dakwah Wal-Irsyad (DDI) Kota \\ Makassar, Indonesia \\ Email: arsyam0505@gmail.com \\ ${ }^{2}$ Universitas Islam Negeri (UIN) Alauddin Makassar, Indonesia \\ Email: kusnadi.umar@uin-alauddin.ac.id \\ ${ }^{3}$ Institut Agama Islam Negeri (IAIN) Sultan Amai Gorontalo, Indonesia \\ Email: zakirahira17@gmail.com
}

Abstrak,

Para ahli pendidikan baik Islam dan Barat sependapat bahwa manusia itu tersusun dengan kombinasi badan dan jiwa. Membimbing dan mengarahkan pertumbuhan badan dan perkembangan jiwa manusia terproses melalui pendidikan. Karena itulah, sehingga manusia disebut sebagai homo educandum (makhluk yang dapat didik) dan homo education (makhluk pendidik). Dari paradigna ini, maka eksistensi manusia adalah sebagai makhluk paedagogiek, yakni ; sebuah makhluk Tuhan yang sejak diciptakannya telah membawa potensi untuk dapat didik dan dapat mendidik.

Kata Kunci: Manusia, Paedagogik, Islam dan Barat

\section{Pendahuluan}

Eksistensi manusia sebagai makhluk paedagogiek, namun dalam pandangan penulis bahwa masalah tersebut masih tetap hangat untuk didiskusikan secara cermat dan mendalam. Berdasar dari latar belakang inilah, maka dapat dirumuskan bahwa pengkajian tentang manusia sebagai makhluk paedagogiek sangat urgen dan signifikan.

\footnotetext{
${ }^{1}$ Dosen Jurusan PAI STAI DDI Kota Makassar

${ }^{2}$ Dosen Jurusan Hukum Tata Negara UIN Alauddin Makassar

${ }^{3}$ Dosen Jurusan Hukum Tata Negara IAIN Sultan Amai Gorontalo
} 
Pada dasarnya pendidikan selalu dikaitkan dengan persoalan manusia. Karen itu, yang pertama-tama harus dicermati adalah tentang hakikat ditinjau dari aspek pendidikan. Dalam pandangan Islam, fithrah manusia adalah suatu potensi keagamaan yang terbawa sejak lahir dan potensi tersebut dapat bertumbuh dan berkembang. Tingkat pertumbuhkan dan perkembangannya, seiring dengan proses paedagogis yang mengintarinya dengan melibatkan pendidikan informal, pendidikan formal, dan pendidikan non formal. Sedangkan dalam pandangan Barat, ditemukan dua kategori. Pertama, pandangan dengan paham nativisme yang menganggap bahwa fithrah manusia tidak dapat diubah melalui proses pendidikan. Kedua, pandangan dengan paham behaviorisme, yang menganggap bahwa fithrah manusia memungkinkan dapat berubah melalui proses pendidikan.

Pandangan Islam dan Barat tentang kedudukan manusia sebagai makhluk paedagogis, bermuara pada suatu implikasi bahwa pandangan Islamlah lebih sempurna. Alasannya, ke-fithrah-an manusia menurut Islam adalah dinamis, sehingga tidak saja terbangun dalam paradigma behaviroisme, tetapi ia terbangun dalam paradigma empirisme.

\section{Pembahasan}

Dalam beberapa ayat-ayat al-Qur'an yang menerangkan tentang proses penciptaan manusia selalu bertitiktolak pada term klahaqa dan ja'ala secara berbarengan. Namun, kelihatannya term khalaqa yang lebih awal disebutkan, lalu menyusul term ja'ala. Misalnya saja dalam ayat berikut ini; 


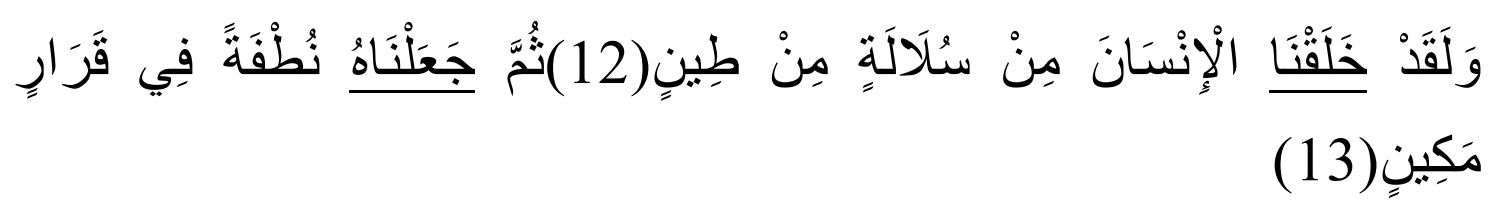

Kata khalaqa (menciptakan) mengandung makna dasar pemberian bentuk pisik dan psikis. Sedangkan kata ja'ala (menjadikan) mengandung makna ganda, dan salah satu maknanya adalah berkonotasi hukum, yakni menetapkan suatu kedudukan. Dengan interpretasi seperti ini yang telah disebutkan, maka dapat dipahami bahwa dalam proses penciptaan manusia itu, ditemukan minimal dua hal yang terkait dengan proses pendidikan, yaitu ;

1. Salah satu cara yang dipergunakan oleh Alquran dalam mengantarkan manusia untuk menghayati petunjuk-petunjuk Tuhan adalah dengan memperkenalkan jati diri manusia itu sendiri, bagaimana asal kejadiannya dan dari mana datangnya. Hal ini sangat perlu diingatkan oleh manusia melalui proses pendidikan, sebab gelombang hidup dan kehidupan seringkali menyebabkan manusia lupa diri.

2. Ayat tentang proses kejadian manusia secara implisit mengungkapkan pula kehebatan, kebesaran dan keagungan Nya dalam menciptakan manusia, sehingga berimplikasi kepada peningkatan wawasan. Ini berarti bahwa pendidikan adalah termasuk sebagai proses peningkatan wawasan pengetahuan.

Pengertian khalaqa dan ja'ala, serta kaitannya dengan hasil interpretasi di atas, maka dapat dirumuskan lebih lanjut bahwa manusia terdiri atas dua subtansi, yaitu jasad atau materi dan subtansi non jasad atau immateri. Jasad merupakan subtansi yang bahan dasarnya adalah materi yang berasal dari alam semesta, dan dalam pertumbuhan serta per-kembangannya tunduk pada ketentuan Tuhan. Sedangkan non jasad merupakan penghembusan roh ciptaan-Nya ke dalam diri manusia, sehingga manusia merupakan benda organik yang 
mempunyai hakekat kemanusiaan (al-haqīqah al-insāniah), serta mempunyai potensi alamiah yang dapat dididik dan juga dapat mendidik.

Dengan memahami makna hakekat penciptaan manusia dan hakekat kemanusiaan sebagaimana yang telah dipaparkan dalam uraian sebelumnya, pada gilirannya akan bermuara pada perumusan tentang manusia sebagai makhluk paedagogiek.

Zakiah Daradjat mendefinisikan bahwa makhluk paedagogiek adalah ;

Makhluk Tuhan yang dilahirkan membawa potensi dapat didik dan dapat mendidik. Makhluk itu adalah manusia. Dialah yang memiliki potensi dapat dididik dan mendidik sehingga mampu menjadi khalifah di bumi, pendukung dan pengembangan kebudayaan. Ia dilengkapi dengan fitrah Allah, berupa kecakapan dan keterampilan yang dapat berkembang. Pikiran, perasaan dan kemampuannya berbuat merupakan komponen dari fitrah itu. ${ }^{4}$

Jika definisi di atas dikaitkan dengan hakikat penciptaan manusia, maka di situ ditemukan rekonsiliasi bahwa sebab utama manusia sehingga ia dapat dididik dan mendidik oleh karena adanya potensi alamiah berupa pisik dan psikis yang dapat bertumbuh dan berkembang melalui proses dan interaksi paedagogis. Dalam pandangan Hasan Langgulung bahwa bahwa manusia yang terdiri atas dua subtansi itu, telah dilengkapi dengan alat-alat potensial dan potensi dasar yang disebut dengan fitrah. ${ }^{5}$ Fitrah inilah (yang dalam batasan defenisi Zakiah Daradjat di atas), harus diaktualkan dan ditumbuh kembangkan dalam kehidupan melalui proses pendidikan. Senada dengan apa yang disampaikan oleh Zakira dkk, bahwa fitra dasarnya manusia sebagai sebuah fenomena menjamurnya

${ }^{4}$ Zakiah Daradjat, Ilmu Pendidikan Islam (Jakarta: Bumi Aksara, 1996), h. 16

${ }^{5}$ Hasan Langgulung, Pendidikan dan Peradaban Islam; Suatu Analisa Sosio-Psikologi (cet. III; Jakarta: Pustaka al-Husna, 1985), h. 215. 
keinginan daerah untuk menerapkan syariah Islam saja belum cukup (The phenomenon of mushrooming the regional desires to implement Islamic sharia alone was not enough). ${ }^{6}$

Pemahaman terhadap fitrah manusia, dapat ditelusuri lebih lanjut dalam QS. al-Rum (30): 30, yakni ;

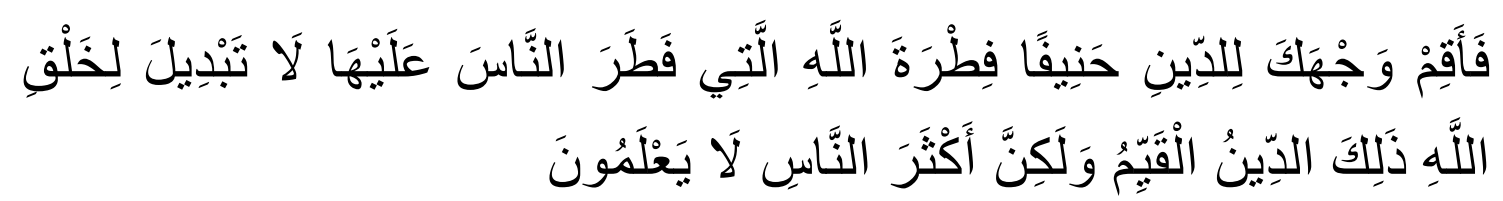

Terjemahnya :

Maka hadapkanlah wajahmu dengan lurus kepada agama (Allah); (tetaplah di atas) fitrah Allah yang telah menciptakan manusia menurut fitrah itu. Tidak ada perubahan pada fitrah Allah. (Itulah) agama yang lurus; tetapi kebanyakan manusia tidak mengetahui. ${ }^{7}$

Hal lain yang dikemukakan al-Ashfahāni bahwa term fithratallahi dalam ayat di atas, mengandung interpretasi adanya suatu kenyatan/daya untuk mengenal atau mengakui Allah yang menetap di dalam diri manusia. ${ }^{8}$ Dengan demikian, implikasi dari makna fithrah adalah suatu kekuatan atau kemampuan yang menetap pada diri manusia sejak awal kelahirannya, untuk komitmen terhadap nilai-nilai keimanan kepada-Nya, cenderung kepada kebenaran dan potensi itu merupakan ciptaan-Nya.

Fithrah tersebut, harus ditumbuh kembangkan secara terpadu oleh manusia dan diaktualkan dalam kehidupan sehari-hari, baik dalam kehidupan

${ }^{6}$ Zakirah, Z., Jumliadi, J., Arsyam, M., Herianto, H., Rusli, M., \& Alwi, A. M. Implementation of The Islamic Local Regulations in Bulukumba Regency.

${ }^{7}$ Departeman Agama, Al-Qur'an dan Terjemahnya (Jakarta: Proyek Pengadaan Kitab Suci al-Qur'an, 1992), h. 645.

${ }^{8}$ Al-Rāghib al-Ashfahāni, op. cit., h. 396 
individu, maupun sosial. Dengan fithrah ini jugalah yang membedakan antara manusia dengan makhluk Allah lainnya, dan karena itu manusia menjadi istimewa dan lebih muliah yang sekaligus berarti bahwa manusia adalah makhluk paedagogiek. ${ }^{9}$ Allah memang telah menciptakan semua makhluk-Nya ini berdasarkan fithrah-Nya, tetapi fithrah Allah untuk manusia yang di sini diterjemahkan dengan potensi dapat dididik dan mendidik, memiliki kemungkinan berkembang dan meningkat sehingga kemampuannya dapat melampaui jauh dari kemampuan fisiknya yang tidak berkembang.

Selanjutnya Abdurrahman Saleh Abdullah mengatakan bahwa melalui proses pendidikan, manusia dapat dengan bebas menumbuhkan fithrah tersebut. ${ }^{10}$ Namun demikian, dalam pandangan penulis bahwa perkembangannya tidak bisa dilepaskan dari adanya batas-batas tertentu, yaitu adanya hukum-hukum yang pasti dan tetap yang menguasai alam (sunnatullah), atau hukum yang menguasai benda-benda atau manusia itu sendiri, yang tidak tunduk dan tidak bergantung kepada kemauan manusia. Hukum-hukum inilah yang disebut taqdī.$^{11}$

Dalam Ilmu Pendidikan, faktor-faktor yang ikut menentukan keberhasilan pelaksanaan pendidikan tersebut antara lain; faktor tujuan,

\footnotetext{
${ }^{9}$ Zakiah Daradjat, loc. cit.
}

${ }^{10}$ Abdurahman Sakeh Abdullah, Educational Theory a Quranic Outlook diterjemahkan oleh H. M. Arifin dengan judul Teori-teori Pendidikan Berdasarkan Al-Qur'an (Cet. II; Jakarta: Rineka Cipta, 1994), h. 84

${ }^{11}$ Taqdīr yang dimaksud di sini adalah keharusan universal atau kepastian umum sebagai batas akhir dari usaha manusia dalam kehidupannya di dunia. Uraian lebih lenjut, lihat Kamaruddin Hidayat, Taqdir dan Kebebasan Manusia dalam Muhammad Wahyuni Nafis (ed.), Rekonstruksi dan Renungan Religisu Islam (Cet. I; Jakarta: Paramadina, 1996), h. 120 
pendidik, peserta didik, alat pendidikan dan lingkungan pendidikan. ${ }^{12}$ Oleh karena itu, maka minat, bakat dan kemampuan, skill dan sikap manusia yang diwujudkan dalam kegiatan ikhtiarnya serta hasilnya akan bermacam-macam.

fithrah manusia itu jikta tidak dikembangkan melalui proses paedagogis, niscaya ia fithrah tersebut kurang bermakna dalam kehidupan. Atau dengan kata lain, dengan pendidikan dan pengajaran potensi (fithrah) itu dapat dikembangkan manusia, meskipun dilahirkan seperti kerats putih, bersih belum berisi apa-apa dan meskipun ia lahir dengan pembawaan yang dapat berkembang sendiri, namun perkembangan itu tidak akan maju kalau tidak melalui proses tertentu, yaitu proses pendidikan.

Menurut Zakiah Daradjat bahwa kewajiban mengembangkan potensi itu merupakan beban dan tanggung jawab manusia kepada Tuhan. Kemungkinan pengembangan potensi itu mempunyai arti bahwa manusia mungkin dapat dididik, sekaligus mungkin pula bahwa suatu saat ia akan mendidik. ${ }^{13}$

Jika kembali dirujuk hakikat penciptaan manusia dan hakekat kehidupan manusia, maka dari sana diketahui bahwa bahwa memang manusia itu secara potensial adalah makhluk yang pantas dibebani kewajiban dan tanggung jawab, menerima dan melaksanakan ajaran Tuhan secara mutlak sebagai penciptanya. 1997), h. 9

${ }^{12}$ Abduddin Nata, Filsafat Pendidikan Islam (Cet. I; Jakarta: Logos Wacana Ilmu,

${ }^{13}$ Zakiah Daradjat, op. cit., h. 17 


\section{Pandangan Islam}

Islam memandang manusia sebagai makhluk paedagogik berdasar pada struktur jasmaniah dan rohaniahnya. Dari struktur manusia ini, maka Allah memberikan seperangkat kemampuan dasar yang memiliki kecenderungan berkembang. Kemampuan dasar itu, disebut dengan fthrah. Dalam pandangan Islam bahwa eksistensi manusia sebagai makhluk paedagogiek, memungkinkan perkembangan fithrah-nya sesuai dengan jalur dan atau lingkungan pendidikan yang dihadapinya.

Adapun Jalur pendidikan yang dimaksud di sini adalah pendidikan formal di lingkungan sekolah; pendidikan non formal di lingkungan masyarakat; dan pendidikan informal di lingkungan rumah tangga. ${ }^{14}$ Ketiga jalur pendidikan ini, disebut dengan tripusat pendidikan. ${ }^{15}$

Jika kemudian fithrah tersebut "dipoles", maka yang pertama dan paling utama menentukan adalah jalur pendidikan informal. Dikatakan demikian karena lingkungan rumah tangga merupakan tempat pertama seseorang mendapat pendidikan. Atau dengan kata lain, sejak pertama sang anak lahir di dunia ini, maka kedua orangtuanyalah yang paling awal memberikan pengaruh. Ini berarti bahwa pertumbuhan dan perkembangan fithrah dimulai dari pendidikan informal,

\footnotetext{
${ }^{14}$ Dalam UU-Sisdiknas 2003, dijelaskan bahwa pendidikan formal adalah jalur pendidikan yang terstruktur dan berjenjang yang terdiri atas pendidikan dasar, pendidikan menengah dan pendidikan tinggi. Selanjutnya, pendidikan non formal adalah jalur pendidikan di luar pendidikan formal yang dapat dilaksanakan secara terstruktur dan berjenjang. Sedangkan pendidikan informal adalah jalur pendidikan keluarga dan lingkungan. Lihat Tim Redaksi Fokusmedia, Undang-undang Sistem Pendidikan Nasional; nomor 20 tahun 2003 (Cet. II; Bandung: Fokusmedia, 2003), h. 4

${ }^{15}$ Abu Ahmadi dan Nur Urbayanti, Ilmu Pendidikan (Cet. I; Jakarta: Rineka Cipta, 1991), h. 170
} 
dimana kedua orang tua bertindak sebagai pendidik secara dwitunggal. Hal ini berdasar pada hadis riwayat Abu Huraerah yakni ;

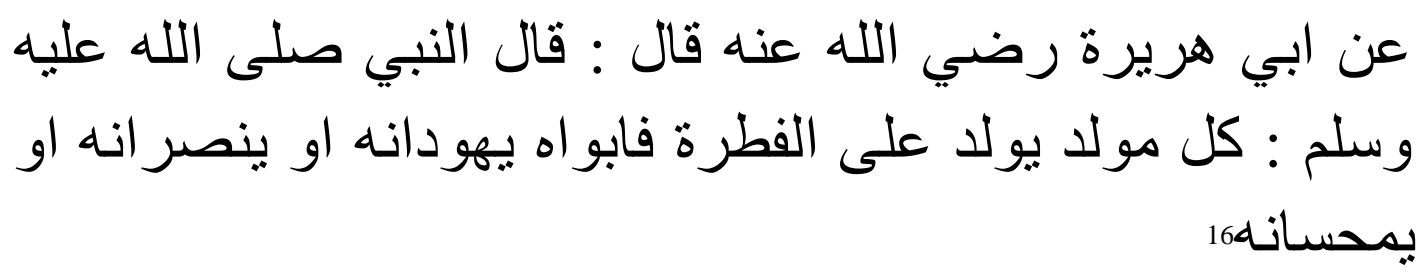

Artinya:

'Dari Abi Hurairah ra, bahwa Nabi saw bersabda: setiap anak yang dilahirkan dalam keadaan fitrah, maka orang tualah yang menjadikan ia Yahudi, Nasrani atau Majusi'.

Konteks hadis tersebut relevan dengan QS. al-Rum (30): 30 sebagai-mana dikutip terdahulu, yang sama-sama membicarakan tentang fitrah keimanan sebagai petunjuk bagi orang tua agar lebih eksis mengarahkan sikap keberagamaan setiap anak secara bijaksana. Berdasarkan hal ini, maka Islam memandang bahwa pertumbuhan dan perkembangan fithrah manusia sebagai makhluk paedagogiek, sangat besar dipengaruhi oleh lingkungan keluarga.

Kaitannya dengan itu, Prof. Dr. H. Mappanganro, MA menyatakan bahwa pada masa-masa tersebut keimanan anak belum merupakan suatu keyakinan sebagai hasil pemikiran yang obyektif, tetapi lebih merupakan bagian dari kehidupan alam perasaan yang berhubungan erat dengan kebutuhan jiwanya akan kasih sayang, rasa aman dan kenikmatan jasmaniah. Peribadatan anak pada masa ini masih merupakan tiruan dan kebiasaan yang kurang dihayati. ${ }^{17}$

\footnotetext{
${ }^{16}$ Imam Ibn Husain Muslim bin Hajjaj Ibn Muslim al-Qusyairi al-Naisaburi, al-Jami Shahih, Juz VIII (Beirut: Dar al-Ma'arif, t.th.), h. 530

${ }^{17}$ Mappanganro, Masa Kanak-Kanak dan Perkembangan Rasa Keagamaan dalam “Warta Alauddin” Tahun XII No. 66 (Ujungpandang: IAIN Alauddin, 1993), h.16
} 
Prof. Dr. H. Bahaking Rama, MS dalam penelitiannya yang berjudul Perilaku Keberagamaan Orang Makassar (tahun 1985), dengan mengambil sampel masyarakat Kelurahan Mangasa Kecamatan Tamalate. Beliau merumuskan bahwa perilaku keberagamaan orang Makassar dalam aspek pelaksanaan shalat terdapat tiga kategori, yakni; amat rajin; rajin; dan kurang rajin. ${ }^{18}$ Lebih lanjut Bahaking Rama menyimpulkan bahwa adanya perbedaan kategori tersebut, disebabkan adanya pertumbuhan dan perkembangan fithrah yang berbeda-beda dalam masyarakat. ${ }^{19}$

Berdasarkan hasil beberapa hasil penelitian di atas, mengindikasikan bahwa proses per-tumbuhan dan atau perkembangan fithrah manusia sebagai makhluk paedagogiek, tetap dipengaruhi oleh faktor lingkungan. Selanjutnya, agar fithrah tersebut bertumbuh dan berkembangan sesuai dengan konsep ajaran Islam, maka umat Islam dituntut untuk menjaga keimanannya dan lalu meningkatkannya melalui proses kependidikan Islam.

Pendidikan Islam berarti pembentukan pribadi Muslim. Isi pribadi Muslim itu adalah pengamalan sepenuhnya ajaran Allah dan Rasul-Nya. Membina

\footnotetext{
${ }^{18}$ Kategori pertama, yaitu amat rajin, adalah mereka tidak meninggalkan shalat lima waktu sehari semalam. Khusyu' dalam mendirikan shalat dan ia juga banyak melakukan ibadah shalat sunat serta rajin berjamaah di mesjid. Kategori kedua, yaitu rajin melaksanakan shalat (tidak meninggalkan shalat wajib) tetapi tidak rajin berjamaah. Mereka juga kurang melaksanakan shalat sunat. Kategori ketiga, yaitu mereka yang kurang melaksanakan shalat baik shalat wajib maupun shalat sunat. Berdasarkan pengkategorisasian tersebut, Bahaking Rama dalam penelitiannya menjelaskan bahwa kategori pertama sangat kecil jumlahnya jika dibandingkan dengan mereka yang masuk dalam kategori kedua dan ketiga. Lihat Bahaking Rama, Prilaku Keagamaan Orang Makassar di Kelurahan Mangasa Kotamadya Ujungpandang dalam "Warta Alauddin No. 64" (Ujungpandang: IAIN Alauddin, 1992), h. 77-87

${ }^{19}$ Lihat ibid.
} 
pribadi Muslim adalah wajib, dan karena pribadi Muslim tidak mungkin terwujud kecuali dengan pendidikan, maka pendidikan itupun menjadi wajib dalam pandangan Islam. Selain itu ajaran Islam menganjurkan agar tidak memanjakan orang lain, atau kreatifitas orang lain, sehingga orang tersebut tidak dapat menolong dirinya sendiri. ${ }^{20}$ Dalam kaidah ushul fikih dikatakan mālā yatimmu syaiun illā bih̄ fahuwa wājibun "sesuatu yang tidak sempurna perbuatan perbuatan wajib kecuali dengannya, maka sesuatu adalah wajib".

\section{Pandangan Barat}

Pandangan agama (Islam) manusia tercipta dari debu dan tanah (materi) kemudian ditiupkan ruh Ilahi (immateri), menggambarkan bahwa hakikat penciptaan manusia dan kehidupan manusia sangat sempurna dengan bergabungnya dua unsur, yakni jasmani dan rohani.

Pandangan Barat tidak ditemukan secara rinci dan teliti mengenai hakikat penciptaan manusia itu sendiri. Bahkan, di kalangan mereka masih banyak menganut teori Darwin yang menganggap bahwa manusia itu tercipta melalui proses evolusi yang panjang (dari monyet). ${ }^{21}$ Para penganut teori Darwin ini, menempatkan manusia sejajar dengan binatang dan menerangkan terjadinya manusia atau hakikat penciptaan manusia dari sebab-sebab mekanis. ${ }^{22}$

\footnotetext{
${ }^{20}$ Arsyam, M., \& Alwi, A. M. (2020, August 18). Konsep dan Makna Kesejahteraan dalam Pandangan Islam. https://doi.org/10.31219/osf.io/2yusv

${ }^{21}$ Lihat Sidi Gazalba, Ilmu Filsafat dan Islam tentang Manusia (Jakarta: Bulan Bintang, 1985), h. 9

${ }^{22}$ Lihat H. Endang Saifuddin Anshari, Ilmu Filsafat dan Agama (Cet. VII; Surabaya: Bina Ilmu, 1987), h. 3
} 
Prof. Dr. H. Azhar Arsyad, MA menyatakan bahwa ada sekian pakar (ahli pendidikan Barat) berbicara tentang manusia yang hanya menggambarkan satu atau dua aspek tentang manusia. Sebagai misal, mereka menggambar-kan bahwa "manusia adalah binatang cerdas yang menyusui". Lebih lanjut Azhar Arsyad berpendapat bahwa misal ini tidak menggambarkan manusia secara utuh. ${ }^{23}$

Adapun dalam pandangan penulis bahwa memang kalau ditinjau dari segi biologis semata-mata, manusia itu adalah sebangsa binatang, karena ia menyusui juga. Binatang punya tulang rusuk dan manusia juga demikian. Tetapi, dalam aspek fisiologis tidaklah sama antara manusia dengan binatang, sebab manusia adalah makhluk yang berakal sementara binatang tidak.

Konsep tentang manusia sebagai makhluk biologis, sampai-sampai menimbulkan suatu studi yang disebut biopaedagogik atau educational biologi yang dilakukan oleh ahli-ahli paedagogik dan psikologi. Demikian besarnya paham biologisme ini, sehingga mereka berpendapat bahwa ada kejahatan dan problem anak nakal adalah karena heriditas (keturunan biologis). ${ }^{24}$ Demikian juga seorang ahli psikologi dari Barat yang bernama Lombrosso ${ }^{25}$ menentukan ciciri yang karakteristik, bagi penjahat-penjahat tertentu.

\footnotetext{
${ }^{23}$ Lihat H. Azhar Arsyad, Superioritas Konsep Pendidikan Islam "Makalah Seminar" (Makassar: IAIN Alauddin, 2002), h. 3

${ }^{24}$ Abu Ahmadi, op. cit., h. 27

${ }^{25}$ Lombrosso bernama lengkap Prof. Dr. dr. Cerase Lombrosso. Ia lahir di VeronaItalia pada tanggal 18 November 1836, dan meninggal dunia di Turis pada tanggal 19 Oktober 1909. William Benton, Encyclopedia Britannica, vol. 14 (Chicago; Lighting to Maximilian, t.th), h. 262
} 
Hal lain pada teori dalam ilmu psikologi pendidikan adalah tentang "phisiognomi". ${ }^{26}$ Tokoh utama yang menganut ajaran phisiognomi adalah Lombrosso. Dengan berpegang pada teori phisiognomi tersebut, maka Lombrosso percaya bahwa sifat-sifat orang sudah terberi sejak lahir dan tidak akan berubah-ubah lagi dalam hidupnya. Demikian pula halnya dengan para penjahat, mereka sudah mendapat bakat-bakat jahatnya sejak lahir dan bakatbakat ini dicerminkan pada wajah seseorang. ${ }^{27}$

Selanjutnya Lombrosso berpendapat bahwa pembawaan manusia sejak lahirnya disebut dapat pula disebut dengan teori delinquento nato, yakni potensi atau bakat yang berpengaruh pada wajah dan potongan tubuh bagi orang bersangkutan. ${ }^{28}$ Karena itu Lombrosso dengan teorinya ini, ia berpendapat bahwa untuk mengatakan seorang itu penjahat atau bukan penjahat dapat dilihat dari wajahnya dan potongan tubuhnya.

Adapun pendapat dari Lombrosso tersebut, diperpegangi maka cukup dengan mempelajari bentuk wajah seseorang atau cukup dengan memperhatikan postur tubuhnya, akan dapat ditebak bahwa orang tersebut adalah jahat atau tidak jahat. Dengan kata lain, berdasarkan raut muka dan bentuk fisiologi (badan)

\footnotetext{
${ }^{26}$ Phisiognomi memiliki beberapa batasan pengertian, yakni

1. Phisiognomi adalah sebuah disiplin ilmu yang secara teoritis mengajarkan bahwa kepribadian seseorang dicerminkan dalam raut mukanya.

2. Phisiognomi dalam arti yang luas, yaitu bukan sekedar mengenai raut muka melainkan keseluruhan bentuk tengkorak.

${ }^{27}$ Ibid. Lihat juga Michael G. Rothember dalam The Encyclopedia Americana, loc. cit

${ }^{28}$ Sarlito Wirawan Sarwono, Pengantar Umum Psikologi (Cet. II; Jakarta: Bulan Bintang, 1982), h. 84-85
} 
tertentu Lombrosso menggolongkan manusia dalam dua tipe, yakni tipe penjahat dan tipe bukan penjahat.

Dengan cara ini diperoleh tiga tipe tengkorak, yaitu ;

1. Dolicocephalic (kepala panjang)

2. Brachycephalic (kepala bulat)

3. Mesocephalic (kepala yang berbentuk antara panjang dan bulat). ${ }^{29}$

Dari tiap-tipe bentuk kepala atau tengkorak itu menunjukkan adanya sifatsifat tertentu atau ciri-ciri kepribadian tertentu yang merupakan pembawa rasil dan tidak dapat diubah-ubah lagi. Paham ini, erat sekali hubungannya dengan paham rasialisasi, yaitu bahwa tiap-tiap ras sudah punya sifat-sifat dan ciri kepribadian sendiri yang tidak berubah-ubah lagi.

Penulis berpandangan bahwa perbedaan tipe-tipe di atas, baik dari sisi raut muka dan postur tubuh seseorang kadang nyata kelihatan dan kadang kadang tidak. Dengan kata lain bahwa kepribadian, karakter, dan sifat manusia tidak selamanya harus berpedoman pada teori phisiagnomi sebagaimana yang dianut oleh Lombrosso.

Selanjutnya masalah kepribadian, karakter, dan sifat manusia, bisa juga dipengaruhi oleh pengalaman-pengalaman dan pengaruh dari lingkungan. Jadi, lingkungan di mana orang itu hidup adalah faktor terpenting yang membentuk kepribadian tersebut. Pendapat penulis ini, merujuk pada pandangan Islam yang menjunjung tinggi ke-fithrah-an manusia sebagai mana dalam QS. al-Rum (30): 30 dan hadis riwayat Abu Huraerah yang telah dikutip terdahulu.

\footnotetext{
${ }^{29}$ Sarlito Wirawan Sarwono, Berkenalan dengan Aliran ... loc. cit.
} 
Eeksistensi manusia dengan melihat faktor heriditas (keturunan) yang bersumber dari orang tua, sebenarnya Islam juga mengakui hal itu, tetapi ia berimplikasi pada kependidikan yang berkonotasi kepada paham nativisme dan penekanannya tetap menjadikan fithrah sebagai potensi dasar beragama "dinulqayyim" yang tidak dapat diubah. Maksudnya bahwa sekali agama Islam itu dianut berdasarkan heriditas, maka fithrah keagamaannya tidak akan mengalami perubahan. Tetapi, bila fithrah dalam arti potensi keberagamaan (melaksanakan ajaran agama) dijadikan sebagai tolak ukur, maka pada gilirannya tingkat keberagamaan itu senantiasa bertumbuh dan berkembang bilamana “dipoles" melalui proses pendidikan.

Paham nativisme ini juga berasal dari pandangan Lombrosso, dan ahli pikir Barat bernama Schopenheuer. ${ }^{30}$ Namun pandangan Lombrosso dan Schopenheuer mengenai manusia sebagai makhluk paedagogiek, tidak sama dengan pandangan Islam. Pandangan Barat yang diwakili oleh Lombrosso dan Schopenheuer, menyatakan bahwa proses kependidikan sebagai upaya untuk mempengaruhi jiwa anak didik tidak berdaya merubahnya. Sedangkan dalam pandangan Islam adalah bahwa proses kependidikan dapat saja mempengaruhi jiwa anak. Salah satu cara untuk mencapai nilai dalam kehidupan adalah dengan melalui aktivitas dakwah. ${ }^{31}$

${ }^{30}$ M. Arifin, op. cit., h. 90

${ }^{31}$ Sainuddin, I. H., S. (2020, August 7). Aktivitas Dakwah di Masa New Normal. https://doi.org/10.31219/osf.io/dejy2 
Pada prinsipnya semua ahli pendidikan Barat sependapat dengan Lombrosso dan Schopenheuer, mengenai konsep manusia sebagai makhluk paedagogiek. John Locke (1632-1704) misalnya, menerangkan hakekat manusia dengan menekankan pembahasan tentang akal sebagai gudang dan pengembang pengetahuan. Menurut John Locke, akan mempunyai kekuatan-kekuatan serta materiil untuk melatih kekuatan-kekuatan itu. ${ }^{32}$ Kelihatannya pandangan John Locke ini, adalah netral. Dikatakan demikian karena secara subtansial John Locke memandang manusia tidak dilahirkan menjadi baik atau buruk, tetapi tergantung pada kekuatan akal menerima pengaruh dari luar (lingkungan).

Adapun dalam psikologi pendidikan menurut John Locke tersebut dikategorikan sebagai paham behaviorisme, yang bersumber dari sarjana psikologi dan pendidikan Amerika Serikat. Hal senada juga dikemukakan oleh Skinner bahwa lingkungan sekitar menentukan perkembangan hidup seseorang, namun ia sendiri juga dapat merubah lingkungan itu. ${ }^{33}$

Ketika kembali menyimak pandangan John Locke dan Skinner, maka dapat dipahami bahwa jiwa anak sejak lahir berada dalam keadaan suci bersih bagaikan lilin (tabularasa) yang secara pasif menerima pengaruh dari lingkungan eksternal. Jadi, dapat dirumuskan bahwa pandangan Barat yang diwakili oleh John Locke dan Skinner, sesungguhnya sejalan dengan pandangan Islam bahwa manusia pada hakekatnya dapat bertumbuh dan berkembang pengetahuannya melalui proses pendidikan.

\footnotetext{
${ }^{32}$ Wasty Soemanto, op. cit., h. 13

${ }^{33}$ H.M. Arifin, op. cit., h. 93
} 


\section{Kesimpulan}

Dalam beberapa uraian di atas, maka dapat disimpulkan bahwa hakekat penciptaan manusia dalam perspektif Islam dengan merujuk pada nash Alquran, selalu bertitiktolak pada term klahaqa (menciptakan) dan atau ja'ala (menjadikan). Kedua term ini, mengimformasikan bahwa manusia itu tercipta atas dua unsur yakni materi dan immateri.

Adapun ke dua unsur tersebut dapat tumbuh dan berkembang melalui proses pendidikan. Dengan demikian, manusia dapat disebut sebagai homo educandum (makhluk yang dapat didik) dan homo education (makhluk pendidik). Dari paradigma ini, menyebabkan keeksistensian manusia sejak kelahirannya, atau dengan kata eksistensi manusia secara fithrawi disebut sebagai makhluk paedagogiek, yakni ; sebuah makhluk Tuhan yang sejak diciptakannya telah membawa potensi untuk dapat didik dan dapat mendidik. 


\section{DAFTAR PUSTAKA}

Abdullah, Abdurahman Saleh Educational Theory a Quranic Outlook diterjemahkan oleh H. M. Arifin dengan judul Teori-teori Pendidikan Berdasarkan Al-Qur'an. Cet. II; Jakarta: Rineka Cipta, 1994

Ahmadi, Abu. Sosiologi Pendidikan. Cet. I; Jakarta: Rineka Cipta, 1991. . dan Nur Urbayanti, Ilmu Pendidikan. Cet. I; Jakarta: Rineka Cipta, 1991

Anshari, H. Endang Saifuddin. Ilmu Filsafat dan Agama. Cet. VII; Surabaya: Bina Ilmu, 1987

Arifin, Ilmu Pendidikan Islam; Suatu Tinjauan Teoritis dan Praktis Berdasarkan Pendekatan Interdisipliner. Cet. II; Jakarta: Bumi Aksara, 1993

Arsyad, H. Azhar. Superioritas Konsep Pendidikan Islam "Makalah Seminar". Makassar: IAIN Alauddin, 2002

Arsyam, M., \& Alwi, A. M. (2020, August 18). Konsep dan Makna Kesejahteraan dalam Pandangan Islam. https://doi.org/10.31219/osf.io/2yusv

Al-Ashfahāni, al-Rāgib. Mu'jam al-Mufradāt Alfāzh al-Qur'ān. Bairūt: Dār alFikr, 1992

Benton, William. Encyclopedia Britannica, vol. 14. Chicago; Lighting to Maximilian, t.th

Daradjat, Zakiah. Ilmu Pendidikan Islam. Jakarta: Bumi Aksara, 1996

Departeman Agama, Al-Qur'an dan Terjemahnya. Jakarta: Proyek Pengadaan Kitab Suci al-Qur'an, 1992

Gazalba, Sidi. Ilmu Filsafat dan Islam tentang Manusia. Jakarta: Bulan Bintang, 1985

Hidayat, Kamaruddin. Taqdir dan Kebebasan Manusia dalam Muhammad Wahyuni Nafis (ed.), Rekonstruksi dan Renungan Religisu Islam. Cet. I; Jakarta: Paramadina, 1996 
Langgulung, Hasan. Pendidikan dan Peradaban Islam; Suatu Analisa SosioPsikologi. cet. III; Jakarta: Pustaka al-Husna, 1985), h. 215.

Mappanganro, Masa Kanak-Kanak dan Perkembangan Rasa Keagamaan dalam "Warta Alauddin" Tahun XII No. 66. Ujungpandang: IAIN Alauddin, 1993

Nata, Abduddin. Filsafat Pendidikan Islam. Cet. I; Jakarta: Logos Wacana Ilmu, 1997

Rama, Bahaking. Prilaku Keagamaan Orang Makassar di Kelurahan Mangasa Kotamadya Ujungpandang dalam "Warta Alauddin No. 64" Ujungpandang: IAIN Alauddin, 1992

Salim, H. Abd. Muin. Fiqih Siayasah; Konsepsi Kekuasaan Politik dalam AlQuran. Cet. II; Jakarta: RajaGrafindo Persada, 1995

Sainuddin, I. H., S. (2020, August 7). Aktivitas Dakwah di Masa New Normal. https://doi.org/10.31219/osf.io/dejy2

Sarwono, Sarlito Wirawan. Pengantar Umum Psikologi. Cet. II; Jakarta: Bulan Bintang, 1982

Sarwono, Sarlito Wirawan. Berkenalan dengan Aliran-aliran dan Tokoh-Tokoh Psikologi. Cet. I; Jakarta: Bulan Bintang, 1978

Soemanto, Wasty. Psikologi Pendidikan. Cet. IV; Jakarta: Rineka Cipta, 1998

Tim Redaksi Fokusmedia, Undang-undang Sistem Pendidikan Nasional; nomor 20 tahun 2003. Cet. II; Bandung: Fokusmedia, 2003

Zakirah, Z., Jumliadi, J., Arsyam, M., Herianto, H., Rusli, M., \& Alwi, A. M. Implementation of The Islamic Local Regulations in Bulukumba Regency. 